methods and that there is hope that with an extended knowledge of localisation we shall find early surgical treatment of still greater use and that just as recent abdominal surgery has been the result of more accurate knowledge of pathological processes and of advanced methods in surgery, so we may hope for similar good results with cranial interference. It was not because abdominal surgery has been successful that I mentioned the subject in connexion with operative treatment in insanity. My object was to illustrate how timorous and tardy interference in one department bad given place to opportune and speedy success in that region, and I think, from illustrations and given references, that I am justified in urging that surgical methods are worthy of consideration in our attack on conditions which in too many instances terminate in hopeless confusion. Cranial surgery is to be employed not because abdominal surgery has been successful but because it (cranial surgery) has been already proved of service in the treatment of insanity, and I trust that the "roving surgeon" may open up to us new ground for treatment and will not be deterred from exploiting this territory by $\mathrm{Dr}$. Mercier's,warning that "trespassers will be prosecuted." I am, Sirs, yours faithfully,

Harley-street, W., Oct. 15th, 1906.

T. Claye Shaw.

PURIN-FREE DIETS.

To the Editors of THE LANOET.

SIRS,-In Dr. W. A. Potts's interesting " Notes on PurinFree Diets" he states that "the Romans at the time they conquered the world were vegetarians." I think Dr. Potts would be greatly puzzled to cite any authority in support of such a statement. Doubtless the early pastoral people of Latium lived largely on lentils and fruit, but the dauntless legions who followed the Roman eagle were coarsely omnivorous. Whether toiling through Syrian deserts or racing over the Apennines or Alps every soldier carried a supply of cured pork, cheese, and flour, usually a suffciency for 12 days when commencing a march. The wealthy Roman classes were carnivorous to a degree not to be measured by modern appetites: "edunt ut vomant, romunt ut edant."-I am, Sirs, yours faithfully,

Worthing, Oct. 1Eth, 1906.

W. W. JONES.

\section{FOOD PRESERVATIVES.}

\section{'To the Editors of THE LANCET.}

SIRs,--There are some other considerations arising out of the use of food preservatives to which, without prejudice to their proper employment, I think reference should be made. For instance, in the case of patients suffering from chronic and other intestinal disorders it would, under the new order of things, be desirable for them to ask their medical attendants explicitly, as they often do about sugar, pepper, sauces, and other common articles of diet, whether boric acid, benzoic acid, formaldehyde, salicylic acid, sulphate of copper, alum, and other ingredients that might be mentioned, should or should not be also taken with their food and if so in what dosage and at what times.

* Not being a physician I am ignorant as to whether the latter information is usually volunteered or required in the consulting-room or is it only forthcoming when symptoms of drug absorption are obviously present? It must, I should think, not infrequently increase the difficulties of treating a disorder if in addition to the medicines the patient is receiving from his adviser he is taking others, though their full physiological effects may not be apparent, from the food merchant. "See that the action of all drugs is suspended before new ones are prescribed," was a frequent remark by one of my most respected and experienced teachers. Why should not all foods which are adulterated be so labeled? Then the salesman and purchaser would be quits. (hen I am, Sirs, yours faithfully,

Berkeler-street, W., Oct. 13th, 1906. REGINALD HARRISON.

\section{THE RECENT SENATORIAL ELECTION AT THE UNIVERSITY OF LONDON.}

To the Editors of THE LANCET.

SIRS,-As one of those who, although a London teacher, nominated Dr. E. G. G. Little, and took an active part in his return, I rejoice at the result. It should stay the iconoclastic tendencies of those in authority at the University of London, for the changes initiated in the curricula for degrees in medicine and surgery have without doubt keen the outcome of panic induced by the falling off of students of medicine in the metropolis. Now all legislation consequent upon panic is dangerous, and the danger in this instance is intensified on reading the report of the standing committee of Convocation on these changes. Our University has won and kept its high position in the medical world by the general and scientific training of its graduates as well as by their professional knowledge. Under the new régime, by the introduction of numerous bypaths to admission, the general education and scientific training are reduced to a valueless minimum, and even the medical examinations can be taken piecemeal-i e., subject by subject. By catering for quantity at the expense of quality our University, I feel sure, will not attract as some think those students who now naturally gravitate to the provincial universities, but will lose its present popularity and undermine its very foundations. Decentralisation in medical education, with the ever increasing facilities for scientific and clinical training which the provincial schools afford, has come to stay. If the London University degree is to be esteemed in the future as it has been in the past, it can only be by maintaining unimpaired its high standard of general and scientific training and its high examinational tests.

London, W., Oct. 11th, 1906.

$=m$, Sirs, yours faithfully,

\section{ANTIVACCINATION TACTICS.}

\author{
To the Editors of THE LANCET.
}

SIRS,--I thank you very much for so promptly supplying a copy of your current issue containing a complaint from the editor of the Clercland Medical Journal of a supposed infringement of his conditions of republication. This is the first, and so far, the only, intimation I have received of $\mathrm{Mr}$. Carter's dissatisfaction with my conduct, which is a purely personal responsibility and not in any way chargeable upon the antivaccinists' cause in general.

The complaint that an equally conspicuous space was not afforded to his letter is very debatable, for a special appendix is devoted to it ; however, I submit a copy of the bocklet for your examination and respectfully direct your attention to the following points: 1 . The three and a quarter small pages derived from the report of the Cleveland Medical Journal were originally copied from the reprint in the Vaccination Inquirer of September, 1902, vol. XXIV., p. 119. All I used the Cleveland Medical Journal for was to correct the excerpt so that its accuracy might place it above the charge of garbling. This appeared desirable because the paragraph in the Vaccination Inquirer was itself a reprint from the Philadelphia Item and Medical Talk; and I believe I am indebted to the publishers of the Cleveland Medical Journal for the copy of their journal by means of which the corrections were made. Thus it will be seen that the paragraph is, in reality, simply a corrected reprint from the Vaccination Inquirer, with one and three-quarters small pages from I'accination Superstition. 2. In his complaint Mr. Carter has omitted to give a copy of my letter of request and a copy of the note in the appendix named. These were :-

The Pubr., Cleveland Medical Journa', Cleveland, Ohio, U S.A. SIR,-Please accept my very best thanks for the copy of your No. 2 issue, with Dr. Friedrich's paper in. Can you allow me to reprint this (complete with the discussion) in a booklet of debates on the subject? Duly acknowledged of course.

16, Granville terrace, Stone, Staffs, 30.4.06. $\quad$ W. J. FurNivat.

$$
\text { Appendix. }
$$

"Since the foregoing matter was prepared for press and partly printed off, the compiler has received a further statement from the editor of the Cleveland Medical Joumal.

The communication was in reply to a request for permission to reprint Dr. Friedrich's paper in toto, together with the whole of the reported discussion thereon, in another booklet of this series entitled, 'Notable Public Debates, Discussions, \&c., on Vaccination.' This it is intended to print in due course, and the statement in question will then be appended to the report; but having in the present booklet reproduced a considerable rescript of Dr. Friedrich's paper and also of Dr. Munn's later notes thereon: the compiler believes it will be more in accord with the wishes of the Cleveland Medical Journal to give currency to the statement in this place also." (Then follows Mr. Carter's statement as per his letter.)

It will thus be seen that the "Debates" for which permission to reprint the report in toto was obtained has yet to come ; 